\author{
BULETINUL INSTITUTULUI POLITEHNIC DIN IAŞI \\ Publicat de \\ Universitatea Tehnică „Gheorghe Asachi” din Iaşi \\ Volumul 67 (71), Numărul 2, 2021 \\ Secţia \\ CONSTRUCŢII DE MAŞINI \\ DOI:10.2478/bipcm-2021-0011 \\ sciendo
}

\title{
OPERATION OF THE PUMPING SYSTEM WITH RODS
}

BY

\section{IONEL SORIN ŞTEFAN* and CRISTIAN PĂTRĂSCIOIU}

Petroleum-Gas University of Ploieşti,

Faculty of Mechanical and Electrical Engineering, Ploieşti, Romania

Received: March 26, 2021

Accepted for publication: May 27, 2021

\begin{abstract}
The asynchronous electric motor is used in the electric stock industry. The inverter adjusts the speed of an asynchronous motor from level 0 to rated speed. An oil pumping plant comprises the bottom machine and the surface machine. The lower machine consists of the depth pump, gas and sand separator, extraction pipe, pump rods. The surface tool includes the pump unit and other equipment. In turn, the pumping unit consists of the rocker, mechanical gearbox, connecting rods, cranks and electric motor. In pump extraction processes, maximum engine speed and / or power is not required. Significant reductions in power consumption can be achieved by adjusting the engine speed with the help of a converter. This solution can reduce production costs and increase productivity by up to $50-60 \%$. The paper is dedicated to studying the regulation of the asynchronous electric motor using a converter controlled by a Siemens PLC. The equipment used is didactic, being produced by the company ASTI Romania.
\end{abstract}

Keywords: oil extraction; asynchronous motor; frequency converter; dynamic characteristics; software.

*Corresponding author; e-mail: sorin.stefan@upg-ploiesti.ro (C) 2021 Ionel Sorin Ștefan et al.

This is an open access article licensed under the Creative Commons Attribution-NonCommercialNoDerivatives 4.0 International License (CC BY-NC-ND 4.0). 


\section{Introduction}

The adjustable electric drives are made for the purpose of implementing the controls to the electric motors, according to the requirements of the technological processes. The adjustable electric drives are implemented by electrical devices placed between the electric power source / regulator and the execution elements of electric motors (Popescu, 2000). These devices are controlled and have the role of modifying the electrical parameters of motor supply: voltage, shape, frequency. The adjustable electric drives can be found in all the industrial branches, one of them being the oil industry (Dimitrie and Hrubaru, 1989).

The specialized literature can be divided into two categories. The first category contains the presentation of the component elements of the adjustable electric drives, having a predominantly didactic character: static converters alternating current (Dimitrie and Micu, 1986), alternators of alternating voltage (Kelemen, 1976), cycloconverters (Kelemen and Imecs, 1983).

The second category includes industrial equipment presentations (astiautomation.ro) and manuals (cache.industry.siemens.com).

The paper presents theoretical and experimental research regarding the regulation of a Siemens asynchronous electric motor using a frequency converter controlled by a Siemens PLC.

\section{Presentation of the Pumping System with Rods}

Of the extraction systems, the deep pumping is the most widespread, being applied in the final phase of exploitation of an oil field. In Romania, the most widespread pumping system is the one based on the use of rods. Fig. 1 shows a deep pumping installation with fringes (ipg.upgploiesti.ro).

The pumping unit is composed of a pump inserted into the well and operated from the surface by means of the pumping rod gasket. The circular movement transmitted from the motor to the gearbox is transformed by the connecting rod-crank system into an alternative rectilinear motion. This movement is transmitted to the piston by means of the rocker and the sealing rod gasket. The operating process of the piston pump is periodic, the pumping cycle being made up of two phases: suction and discharge.

\section{The Asynchronous Electric Motor}

The pumping unit uses an asynchronous electric motor. Asynchronous electric motors are the most used in drives with AC machines. In these engines the speed decreases slightly with the load and for this reason their mechanical characteristic is called a derivative type characteristic. Starting an asynchronous motor must be such that: 
- the torque developed by the engine is large enough that the engine can reach the rated speed;

- the current absorbed by the motor should be sufficiently small, so as not to cause disconnection of the motor due to the action of the protection system at maximum current.

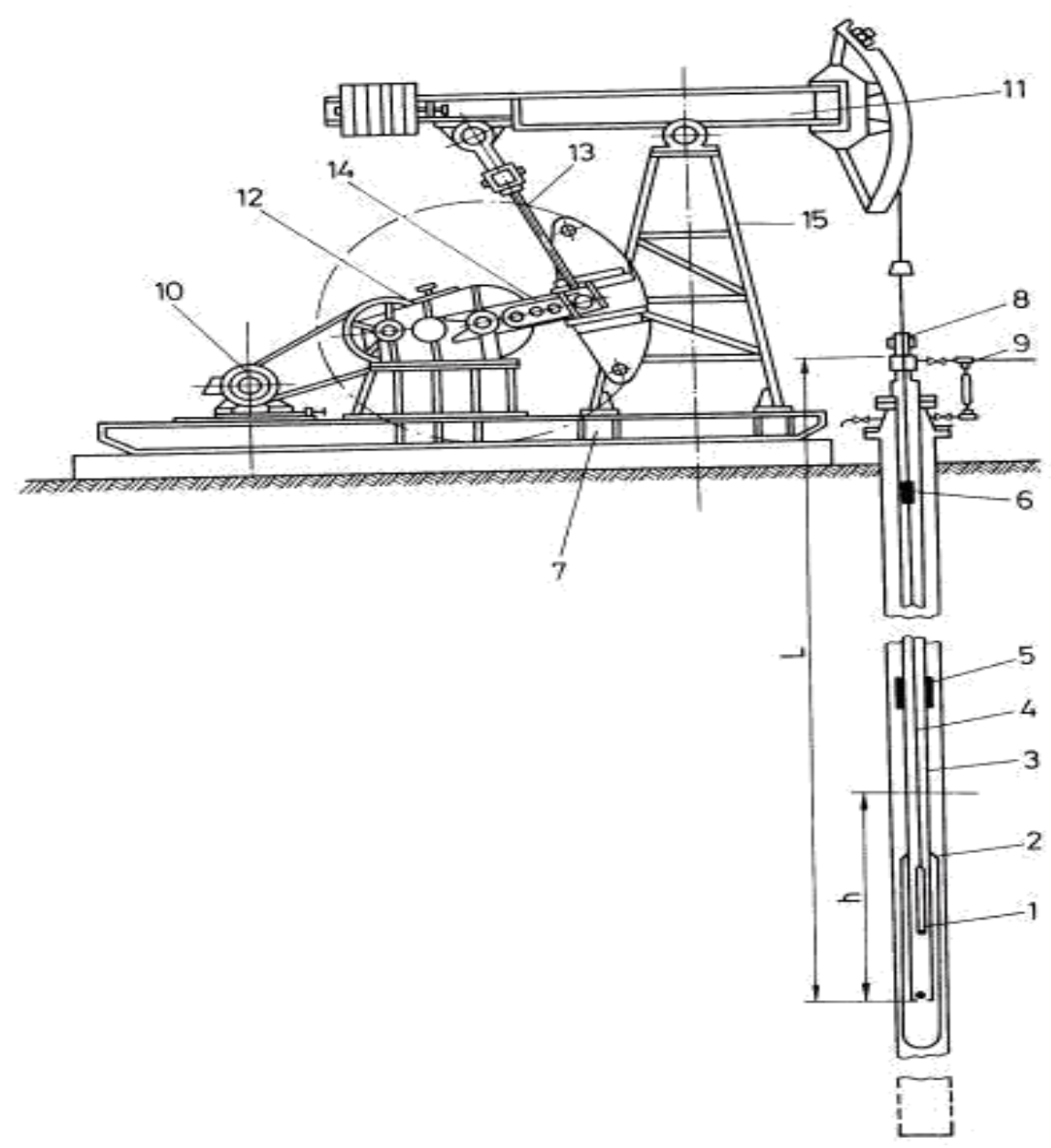

Fig. 1 - Piston pump unit: 1 - depth pump; 2 - bottom separator for gas and sand; 3 - extractive pipes; 4 - pumping rods; 5 - anchor for extraction pipes; 6 - paraffin wipes; 7 - frame; 8 - pumping head; 9 - mixing pipe; 10 - electric motor; 11 - swing; 12 - gearbox; 13 - connecting rod; 14 - cranks; 15 - supporting goat.

The starting conditions of an engine are quantified by the ratio of the starting current to the rated current and the ratio of the starting torque to the rated torque. 
Starting the motors with the rotor in the cage (short-circuit rotor) differs from that with the motors with the winding rotor, because there is no possibility of introducing external impedances into the rotor. Most engines do not allow starting by direct connection to the grid and require special starting methods that aim to reduce the current shock at the same time as obtaining the best energy parameters. In this case, starting the engine is done by applying to the mayor's terminals a system of reduced voltages, which can be obtained by the following methods:

- Direct connection to the mains supply, the specific method for small motors;

- With the help of an autotransformer;

- Starting with the star - triangle switch;

- Starting with the variation of the supply voltage frequency.

\section{Research on Adjusting the Speed of the Asynchronous Electric Motor Using a Static Frequency Converter}

The speed $\mathrm{n}$ of the reversing magnetic field for an asynchronous electric motor is given by the relation (Manole, 2004)

$$
n=60 \frac{f(1-s)}{p}(\mathrm{rot} / \mathrm{min})
$$

where $f$ is the frequency of the supply voltage; $p$ - number of poles; $s$-slipping.

Changing the asynchronous motor speed is possible by modifying the three variables in the relation (1), in the literature the following variants are treated:

- changing the number of pairs of poles $p$;

- modifying the sliding by changing the rotor resistance;

- changing the frequency $f$, supply voltage.

Of these variants, the most important is to change the frequency of the electric current supplying the motor through a static frequency converter. The research paper is dedicated to the study of the regulation of the asynchronous electric motor using a frequency converter controlled by a Siemens PLC. The equipment used is didactic, being produced by the company ASTI Romania, Fig. 2 (astiautomation.ro).

Sinamics G120 is a frequency converter for electric motors, modularly designed, including the control unit (CU) and power module (PM) for engines with a power range from $0.37 \mathrm{~kW}$ to $250 \mathrm{~kW}$.

It comprises 3 basic components:

a) Power module that supplies voltage to the motor. 
b) The control unit that controls and monitors the power module.

c) Basic Operator Panel (BOP-2) and Intelligent Operator Panel (IOP), control elements that are used to operate and monitor the converter.

Figure 3 shows how to connect the Sinamics G120 module to an electric motor and a computer (astiautomation.ro).

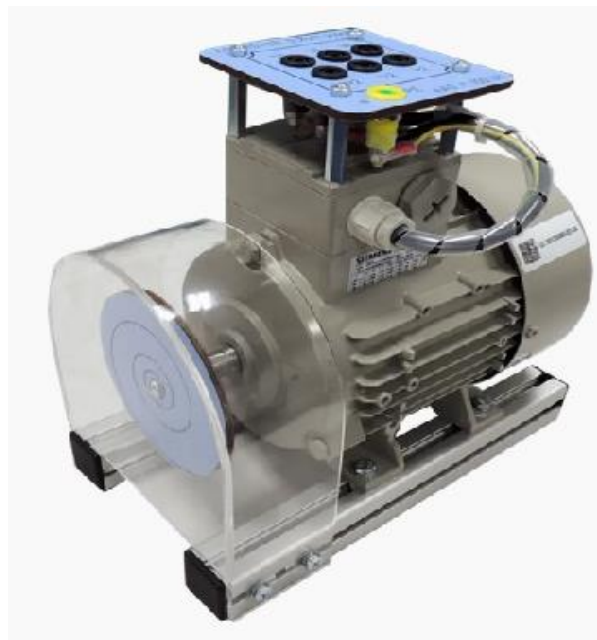

a)

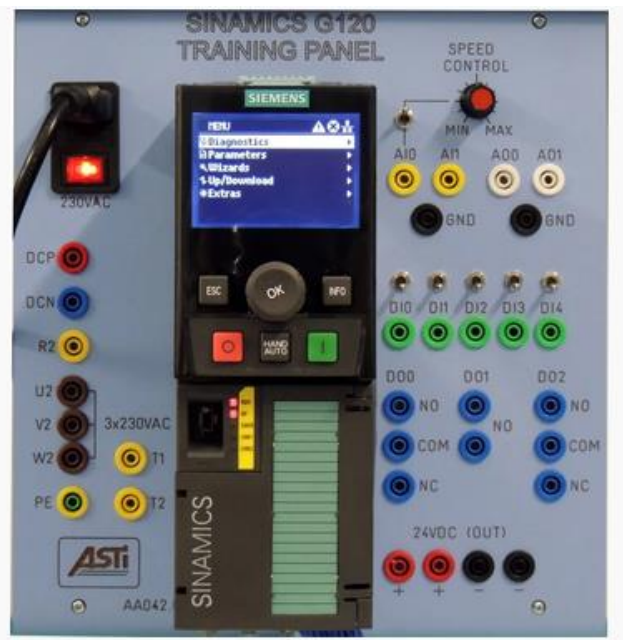

b)

Fig. 2 - The ASTI teaching equipment: a) the electric motor; b) numerical equipment for speed monitoring and control.

SINAMICS is a software package developed by SIEMENS and used for monitoring and tuning the engines produced by SIEMENS. All SINAMICS software versions are based on the platform concept, with standardized tools for application configuration, data storage and automation communication. SINAMICS is part of the Siemens "Total Integrated Automation" concept.

STARTER is the tool used to initialize all Sinamics units. During the initialization period, the 250 central unit is configured automatically and the motor connected via driv-cliq is recognized and the data of the motor and the encoder are loaded.

The activation of the communication connection between STARTER and the physical unit is another step. To do this, connect the target device from the Project menu. The STARTER compares the configuration found online with the project stored in STARTER.

So far, the following elements have been studied: the programming mode of the programmer; PLC data acquisition; creation and updating of the experimental database; configuration of the programming environment in order 
to visualize the dynamic evolution of the purchased parameters; adjusting engine speed in the absence of load.

The electric motor assembly - Sinamics G120 - computer was used to study the operation of the system and its characteristics. After the Sinamics configuration, tests were performed on the electric motor operation at various speeds imposed on the electric motor. The system in figure 4 is presented the evolution of the frequency of the voltage generated by the frequency converter for the speed of $1500 \mathrm{rpm}$.

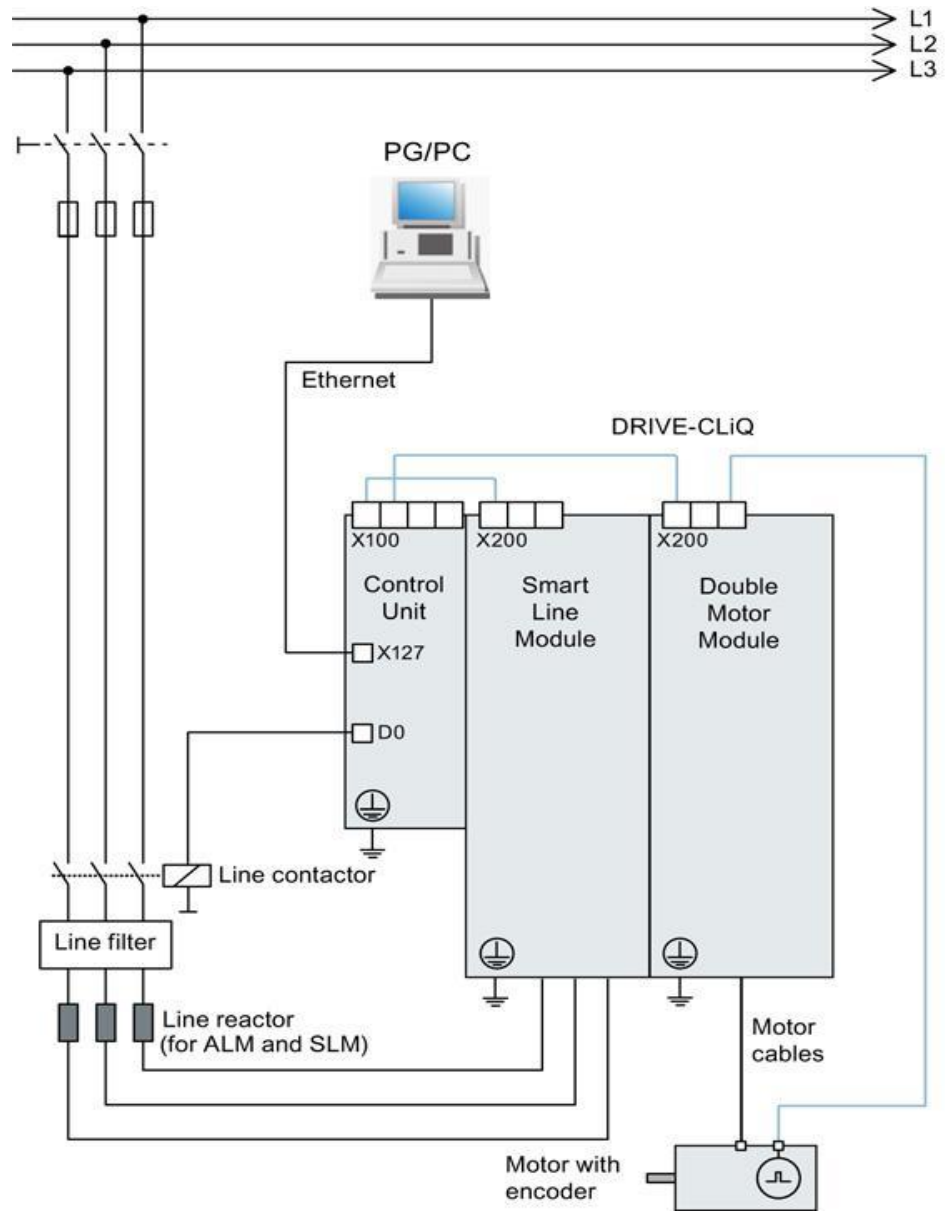

Fig. 3 - The connection of the Sinamics G20 module to an electric motor and monitoring the parameters.

Due to an accumulation of errors due to the analog-numerical conversion associated with the speed transducer, the numerical-analog conversion associated with the inverter, the actual frequency of the alternating voltage generated by the 
static frequency converter is not constant. In this experiment, the frequency fluctuated around $50.355 \mathrm{~Hz}$, with minima and maxima of 50.335 and $50.375 \mathrm{~Hz}$ respectively.

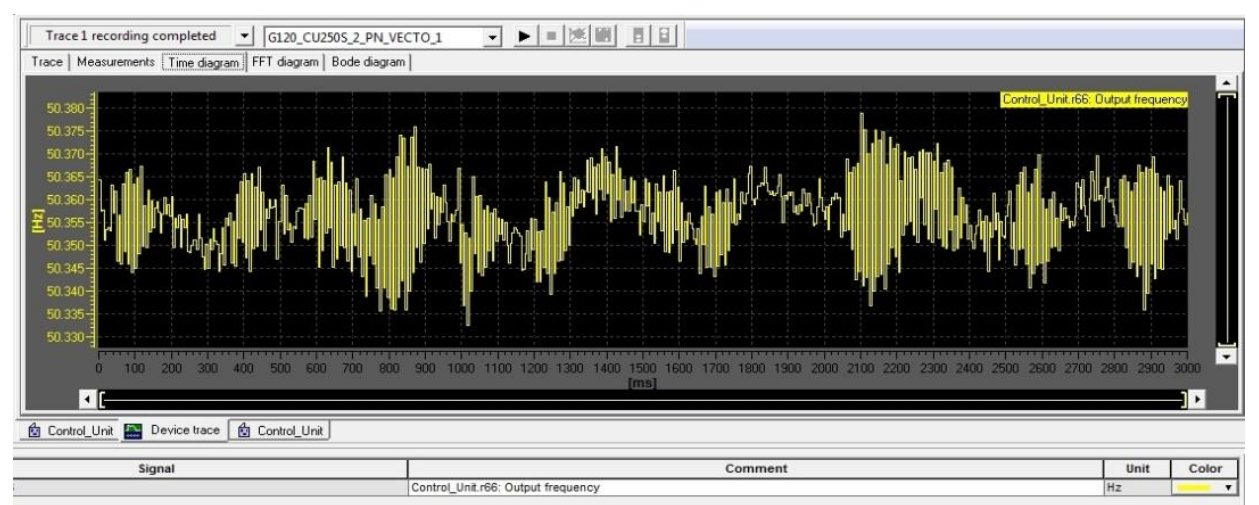

Fig. 4 - Results of the system tested for $1500 \mathrm{rpm}$.

Figure 5 shows the evolution of the frequency of the voltage generated by the frequency converter for the speed of $750 \mathrm{rpm}$. And in this experiment, the frequency generated by the static frequency converter oscillated around $33.355 \mathrm{~Hz}$, with minima and maxima of 33.58 and $33.67 \mathrm{~Hz}$ respectively.

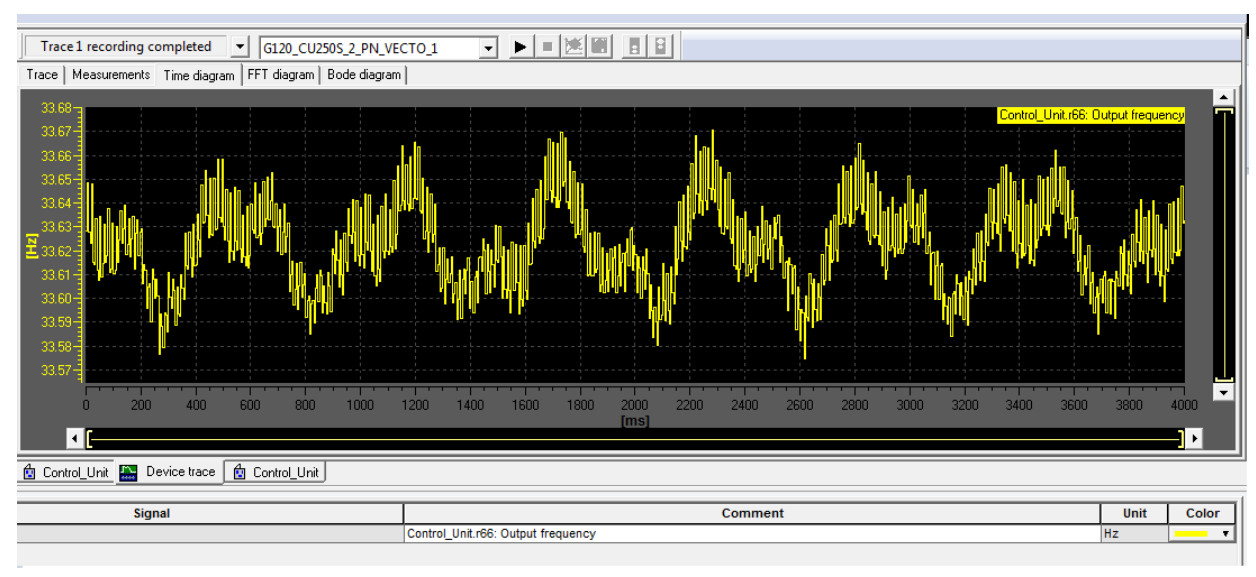

Fig. 5 - Results of the system tested for $750 \mathrm{rpm}$.

\section{Conclusions}

Both experimental tests highlighted the following:

a) Electric motor structure - Sinamics G120 can adjust the electric motor speed in good conditions. 
b) The quality of the frequency adjustment of the alternating current is very good, the variation of the frequency generated with maximum deviations of $0.6 \%$.

c) The SINAMICS software package was used to monitor and regulate the speed of the electric motor.

d) The need for further research in this field.

\section{REFERENCES}

Dimitrie A., Hrubaru O., Aplicaţii ale convertoarelor statice de putere, Editura Tehnică, Bucureşti, 1989.

Dimitrie A., Micu D., Invertoare şi redresoare cu parametri energetici ridicaţi, Editura Tehnică, Bucureşti, 1986.

Kelemen A., Acţionări electrice, Editura Didactică şi Pedagogică, Bucureşti, 1976.

Kelemen A., Imecs M., Electronica de putere, Editura Didactică şi Pedagogică, Bucureşti, 1983.

Manole Gh., Sisteme automate de acţionare electromecanică, Editura Universitaria, Craiova, 2004.

Popescu M., Convertoare statice - suport curs, Universitatea din Craiova, 2000.

https://cache.industry.siemens.com/dl/files/780/99683780/att_863315/v1/G120C_List_ Manual_LH13_0414_eng.pdf

http://ipg.upgploiesti.ro/attachments/article/103/ECHIPAMENTUL\%20SONDELOR\% 20IN\%20POMPAJ\%20CU\%20PRAJINI.pdf

https://www.astiautomation.ro/ro/products-2/

\section{ACTIONAREA INSTALAȚIEI DE POMPARE CU PRĂJINI}

\section{(Rezumat)}

Motorul electric asincron se foloseşte în industrie pentru acţionarea componentelor mecanice. Convertizorul static de frecvenţă este utilizat pentru reglarea turaţiei motorului asincron cu rotor în scurtcircuit, de la valoarea 0 pana la turaţia nominală. $\mathrm{O}$ instalaţie de pompare a țițeiului cuprinde utilajul de fund şi utilajul de suprafaţă. Utilajul de fund se compune din pompa de adâncime, separatorul de fund pentru gaze şi nisip, ţevile de extracţie, prăjinile de pompare, ancora pentru ţevile de extracţie, curăţitoarele de parafină. Utilajul de suprafaţă cuprinde unitatea de pompare, capul de pompare şi conducta de amestec. În cadrul proceselor de extracție prin pompaj nu este nevoie de turația și/sau puterea maximă a motorului. Reduceri semnificative ale consumului de energie se pot obține prin reglarea turației motorului cu ajutorul unui convertizor de frecvență. Această soluție poate reduce costurile de producție și crește productivitatea cu până la 50-60\%. Lucrarea este dedicată studiului reglării motorului electric asincron utilizând un convertizor de frecvență comandat de un PLC Siemens. Echipamentul folosit este didactic, fiind produs de firma ASTI România. 